\title{
The Costs of Domestic Political Unrest
}

\author{
Alex Braithwaite and Jeffrey Kucik \\ University College London \\ AND \\ Jessica Maves \\ Pennsylvania State University
}

\begin{abstract}
Does domestic political unrest deter foreign direct investment (FDI)? And what are the longer term impacts of unrest upon the market? Most theories suggest that investors are deterred by unrest. However, empirical research returns only marginal support. We argue that these mixed results stem from the conflation of the distinct tactics and outcomes of political unrest. Violent forms of unrest increase uncertainty and risk. By comparison, nonviolent forms of unrest are shown to more frequently achieve their goals and increase the prospects for democratic change and market stability. In addition, investors avoid markets where campaigns have ended in failure, defined as the campaign not achieving their stated political aims. Failed campaigns often precipitate a cycle of unrest that create greater uncertainty over the longterm stability of a state. We find strong evidence in favor of our propositions, even after taking political motivation and non-random selection into account.
\end{abstract}

How does domestic political unrest affect the market? Domestic unrest is increasingly common in the postWorld War II period. ${ }^{2}$ It surpasses interstate conflict in both the number of incidents and in its human cost (Kaldor 1999; Gleditsch, Wallensteen, Eriksson, Sollenberg, and Strand 2002). The frequency and severity of unrest has piqued academic interest in its causes and consequences. Existing work finds, among other things, that unrest heightens uncertainty over democratic transitions (Hegre, Ellingsen, Gates, and Gleditsch 2001) and increases the likelihood of violence at home and in neighboring states (Buhaug and Gleditsch 2008; Lake and Rothchild 1998).

Unrest's effects on the market are less well understood. Recent research shows that political unrest stunts growth

Alex Braithwaite is Associate Professor in the School of Government and Public Policy at the University of Arizona. His research, exploring the causes and geography of political violence has been published in Journal of Politics, British Journal of Political Science, Journal of Peace Research, and elsewhere.

Jeffrey Kucik is Assistant Professor of Political Science at City College of New York. His work focuses on issues in international political economy, including the political economy of conflict. He also investigates the distributional effects of membership in international economic institutions.

Jessica Maves Braithwaite is Assistant Professor in the School of Government and Public Policy at the University of Arizona. Her research focuses upon the role of domestic political institutions in civil conflict processes. Her research has been published at Journal of Politics and International Studies Quarterly.

${ }^{1}$ Author's notes: We thank William Thompson and two anonymous reviewers for their valuable comments and suggestions on previous drafts of this article. Any remaining errors are our own. Braithwaite thanks the Economic \& Social Research Council of the UK (ESRC) for financial support (Grant ref: RES-000-22-4437). The data and replication file used to generate the results presented in this article are available through $I S Q$ 's data archive.

2 "Domestic political unrest" is defined here to encompass the full range of campaigns led by non-state actors challenging a government, including strikes, protests, riots, and armed rebellions. We refer to unrest, instability, and conflict interchangeably. and development (Collier 2003; Sachs 2006). ${ }^{3}$ However, the precise channels through which unrest affects growth, development, and the market more generally, remain open to investigation. In this paper, we explore one of these channels: how unrest deters foreign direct investment (FDI). ${ }^{4}$ We focus on two key questions. First, to what extent does unrest deter inward investment during the period of ongoing instability? Second, does unrest have longer-term effects on investment flows after instability ends?

Literature on international investment shows that markets characterized by risk - whether that risk derives from autocratic institutions (Jensen 2008), corruption (Bénassy-Quéré, Coupet, and Mayer 2007), or a myriad other factors-find it difficult to attract FDI. However, in spite of these findings, there is only limited evidence that political unrest deters inward FDI. Some studies show that less FDI flows into countries undergoing periods of unrest (Schneider and Frey 1985) while others cast doubt on the durability of this relationship (Büthe and Milner 2008). This empirical ambiguity highlights a shortcoming in past approaches. Previous work, with a few exceptions (Busse and Hefeker 2007; Li 2006), pays too little attention to variation across periods of unrest, particularly with respect to the tactics political actors use. Yet, the tactics actors use- that is, whether they employ violence or nonviolence-are a crucial determinant of the success of political campaigns. Specifically, non-violent campaigns are far more likely to successfully achieve their goals

\footnotetext{
${ }^{3}$ Low growth is itself related to political unrest. There is evidence that poor economic performance-defined as low growth and high inequalityincreases the likelihood of unrest. As a result, political instability leads to "conflict traps" in which unrest's deleterious effects on the economy foster a cycle of continued unrest.

${ }^{4}$ We do not make a claim about the net welfare benefits of FDI. A lengthy literature speaks to this topic and finds mixed evidence regarding whether FDI promotes growth and development. We only assume that markets want to attract foreign investment.
} 
(Chenoweth and Stephan 2011). Successful campaigns, in turn, are less vulnerable to conflict renewal.

These relationships have implications for how we understand unrest's effects on the market. The extent to which unrest deters FDI is conditioned by the same factors that affect political stability broadly-that is, violence and success. We assume that capital is sensitive to uncertainty about the future. Investors are wary of markets where there is a high likelihood of continued political instability. We make two main arguments. First, FDI flows are lower into markets experiencing violent unrest than into markets not experiencing violence. Violence signals greater risk to the market because, for the reasons just cited, it is associated strongly with a greater chance of prolonged instability. ${ }^{5}$ Violent campaigns are longer in duration and more likely to result in additional unrest.

Second, the costs of unrest likely extend beyond its initial duration. We argue that unrest's longer term effects are shaped by how campaigns end. Specifically, successful campaigns are far less likely to precipitate subsequent (violent) unrest. Unsuccessful campaigns, on the contrary, often foreshadow additional instability in the near future. FDI inflows should therefore be lower into states where the specter of continued instability looms over the market - that is, where campaigns have unsuccessful outcomes.

We test the validity of these claims using data on political unrest disaggregated by tactical type and outcome and find strong support for our predictions. Unrest (of all forms) is mildly associated with reduced FDI during the years of ongoing instability. However, a closer look, in which we disaggregate campaigns based on their tactics, reveals that only violent unrest deters investment. Non-violent unrest is statistically indistinguishable from periods of peace. We then explore the legacy unrest leaves on the market and find that success is a significant determinant of FDI after instability ends. Looking at a sample of post-unrest years, we show that markets attract comparatively more FDI in the wake of successful campaigns than they do after unsuccessful ones. This result holds even if success means additional turmoil from any resultant secession or change of regime. We take special note of the possibility of selection bias in the estimates and find that the results are robust to corrections for non-random selection into unrest.

We conclude that a fuller account of how political unrest affects the market must consider variation in the precise nature of instability. The findings suggest a potential source of ambiguity in the current evidence. Moreover, the results point to a specific channel through which unrest shapes states' longer term development trajectories. Campaigns that end successfully leave a comparatively less damaging legacy on the market. This evidence is important given that conflict's deleterious effects on the domestic economy foster a cycle of instability. States emerging from successful campaigns may be better positioned to avoid slipping into a "conflict trap" (Collier 2003).

The article proceeds as follows. First, we review the relevant literature on political unrest and FDI, before outlining our own logic, which suggests that variation in the tactics and outcomes of campaigns of unrest account for differential impacts of unrest on FDI inflows both during and after unrest. Second, we present our research design

${ }^{5}$ Even if non-violent campaigns are larger in scale with respect to levels of participation, they more regularly result in stable political outcomes. and evidence, including a variety of tests designed to probe the durability of our results. In the final section, we highlight the broader implications of these findings.

\section{Background and Theory}

Existing work emphasizes foreign direct investment's sensitivity to political risk. FDI is characterized by high sunk costs and comparatively lower mobility, which implies that non-negligible costs are incurred when exiting markets. As a result, investors are wary of uncertainty in host markets. There is strong evidence that risky markets enjoy relatively lower levels of inward investment, whether that risk derives from fear of expropriation (Li 2009; Biglaiser and DeRouen 2006), government corruption (Habib and Zurawicki 2002), armed interstate conflict (Barbieri and Reuveny 2005), or a variety of other factors. By extension, it ought to likewise hold that domestic political unrest, broadly defined, deters FDI.

In spite of this literature, there is only mixed evidence that domestic political unrest shapes inward investment flows. Early survey work showed that firms placed unrest high on their lists of priorities when selecting among host markets (Agarwal 1980; Aharoni 1966). In addition, foundational econometric studies demonstrated that political unrest and concerns over property rights protections where important determinants of FDI flows (Schneider and Frey 1985). As a result, states with histories of unrest received lower levels of inward FDI than their more stable counterparts.

However, there have been a series of studies that cast doubt on this relationship. Several early papers found that the correlation between unrest and FDI greatly diminishes (or vanishes entirely) once controlling for economic factors such as market potential (Bennett and Green 1972; Greene and LaPalombara 1974). More recent studies echo these results. Some note that FDI is now more vertical than in previous decades and, therefore, the nature of the risks firms face has changed (Büthe and Milner 2008). Furthermore, increasingly widespread democratic institutions and greater numbers of formal interstate economic agreements both act to institutionalize promises made by governments to respect the rights of investors (Jensen 2008).

Empirical ambiguity in the relationship between unrest and investment derives from the fact that too few studies appreciate variation in the nature of unrest. ${ }^{6}$ Many studies conflate the tactics and outcomes of episodes of political unrest, relying on one aggregate indicator of instability - for example, Büthe and Milner (2008). ${ }^{7}$ That simplified approach helps identify whether a broad relationship exists between unrest and FDI. However, it overlooks important differences across periods of political unrest, particularly with respect to the tactics that campaigns use to achieve their goals and the outcomes of those campaigns.

\footnotetext{
${ }^{6}$ The most notable exception to this recent trend is $\mathrm{Li}$ (2006). Indeed, $\mathrm{Li}$ offers the most direct and systematic extant assessment of the puzzle prioritized in this paper. Combining empirical and theoretical innovation, $\mathrm{Li}$ focuses upon investors' anticipation of the onset and impact of political unrest. Li distinguishes between three types of violent unrest: transnational terrorism, civil war, and interstate conflict. His analyses demonstrate that, with some exceptions, unanticipated forms of violent unrest have a more detrimental impact on investments than do their anticipated counterparts.

7 This is typically taken from the Banks (2008) dataset, which provides an index of unrest comprised of, for example, the number of strikes, rebellions, and coups that occur in a given country-year.
} 
In this article, we argue that understanding the relationship between political unrest and the market requires a closer look at variation across periods of instability. This is not just a research design concern. There are strong theoretical reasons to think that variation in tactics and outcomes matter for the impact that unrest has on investment flows. In short, violent tactics and unsuccessful campaigns both indicate greater uncertainty than do nonviolent tactics and successful campaigns. As a result, we should only expect investors to respond to unrest under certain conditions, thereby helping clarify the existing ambiguity in the findings. We elaborate on these claims in the following section.

\section{Does Unrest Deter FDI?}

Our argument starts from the assumption that investors consider the relative stability of a country when selecting among potential host markets. We do not assume that investors have full information. We simply assume that they are wary of markets perceived to exhibit high levels of instability (either today or in the future). ${ }^{8}$

Existing work shows that investment levels are linked inextricably to political instability. Specifically, FDI levels are positively correlated with stability (Busse and Hefeker 2007). This is because stable political environments create more attractive investment opportunities for firms. Studies show that firms invest more heavily in markets that protect property rights (Markusen 2001), have reliable legal systems (Asiedu 2006), and have transparent regulations (Jensen 2008). All of these traits help firms determine more accurately their expected returns on their investments. Under conditions of instability, this is more difficult because changes in the regulatory and legal landscapes are harder to anticipate. For example, existing works shows that instability leads to a depreciation in property rights protection (Svensson 1998).

In addition, FDI's sunk costs leave firms vulnerable to obsolescing bargaining power and to fears of outright expropriation. Stable policy environments significantly reduce these risks by limiting ad hoc opportunism on the part of the state (Olson 1993). In light of these reasons, firms will choose more stable political climates, on average, when selecting from their menus of potential host markets.

Firms' sensitivity to risk has implications for levels of FDI flowing into markets experiencing unrest. The literature cited above provides a strong theoretical and evidential basis for thinking that any form of instability potentially deters inward investment. The same relationship ought to hold for domestic political unrest. Indeed, the occurrence of everything from a large-scale strike to a civil war can have a disruptive effect on the domestic economy (see, for example, Murdoch and Sandler (2004) and Collier (1999)). These incidents can lead to new costs for firms, including the renegotiation of labor practices (in the case of strikes), to destroyed productive capacity (in the case of civil war), or any number of

\footnotetext{
${ }^{8}$ One challenge to this assumption is the possibility that some investors may be attracted to, rather than deterred by, unrest. Political instability may create space for opportunism by investors, allowing them to get better deals from rent-seeking politicians or regulators. However, these opportunities are likely to be industry-specific and idiosyncratic in nature, not something that applies to the entire market. We do not test predictions about specific firms in this paper. However, if this is true, then it would bias our results against finding support for our theory, thereby creating a more conservative test.
}

direct costs to the firm that reduce returns on investment.

More generally, unrest may create heightened uncertainty over policy as governments move to tighten the grip on opposition groups. Legal systems may be relaxed when governments attempt to repress the opposition (for example, the declaration of emergency law in Egypt following the assassination of Anwar Sadat, and martial law in the Philippines in the face of civil conflict under President Ferdinand Marcos). Governments' incentives to expropriate foreign assets may also increase when the security of their tenure is uncertain (Li 2009). Thus, unrest can exacerbate precisely the kinds of political risks to which firms are sensitive.

Firms' investment decisions are made more complicated by the fact that investors may be unsure about future risks when unrest first occurs. Given that investors have incomplete information about the severity, duration, and outcome of conflicts, the "safest" action may be to entirely avoid a market in which any form of unrest breaks out ( $\mathrm{Li}$ 2006). For these reasons, risk-averse investors may be uniformly pessimistic about markets experiencing a period of unrest. Thus, our initial expectation is that,

H1. FDI flows are lower into states experiencing a period of unrest than into states not experiencing unrest.

Our first hypothesis focuses on firms' general wariness of the political instability that may results from periods of unrest. However, this logic does not consider variation in the precise nature of unrest. Instead, it assumes that all periods of unrest have the potential to deter FDI. Our core insight is that investors' perceptions of stability are conditioned by specific traits of unrest. Not all periods of unrest are created equal. They vary with respect to political motivation, breadth of participation, duration, and numerous other characteristics. These traits are unlikely to provide the market with precisely the same information about the short- and long-term prospects for political stability. Consequently, campaigns will vary in their effects on the market.

Here we focus on two sources of variation known to affect stability: the tactics campaigners use and the outcomes of those campaigns. First, it is necessary to distinguish campaigns by their predominant tactical formthat is, whether they employ violence or non-violence as their primary mode of contestation. Existing work shows that a greater proportion of campaigns leading to the successful removal of governments and significant changes to state policies rely on non-violent resistance (Chenoweth and Stephan 2011). This pattern owes to the fact that non-violent movements typically enjoy higher levels of participation by regular citizens than do violent movements. On average, non-violent campaigns have four times as many participants as violent ones. In addition, 20 of the largest 25 campaigns between 1900 and 2010 were non-violent. This is partly because the costs incurred by individuals are considerably lower when campaigns are non-violent (Kurzman 1996). ${ }^{9}$

Greater participation is also observed amongst elite groups separate from the general civilian population. Non-violent campaigns are significantly more likely to

\footnotetext{
${ }^{9}$ Fewer people may support the use of violence in principle. Moreover, the risks borne by participants are considerably lower when tactics are non-violent.
} 
result in defections from the state's military and government. The literature on non-violence shows that the loyalty of government officials shifts more toward campaigns challenging the government as the probability of success increases (Greene and LaPalombara 1974; McAdam, McCarthy, and Zald 1996). Furthermore, these defections are more likely when the campaign has a large number of supporters (Chenoweth and Stephan 2011).

Both of these processes - more widespread public participation and greater numbers of defections from the regime-are fundamental to the greater ability of nonviolent movements to successfully undermine autocratic institutions and despotic leaders (DeNardo 1985; Weinstein 2007), as illustrated by the successes of movements to overthrow Marcos in the Philippines and the Kuchma regime in Ukraine. Following a rigged election in 1986 that saw incumbent Ferdinand Marcos comfortably defeat his opponent Cory Aquino, many members of the regime openly denounced him and Filipino military forces set up bases around the capital of Manila to successfully aid the throngs of pro-Aquino protesters in overthrowing the sitting president (Montiel and Chiongbian 1991).

In Ukraine, millions of citizens amassed in Kiev's Independence Square and across the country in reaction to allegations of vote fraud in the 2004 presidential election. Demanding justice for the opposition candidate, Victor Yushchenko, Ukrainians participating in this "Orange Revolution" succeeded in winning the support of members of the armed forces, as well as ultimately achieving the removal of incumbent Leonid Kuchma (Karatnycky 2005).

Indeed, it appears that members of the Security Service of Ukraine (the SBU, an organization that succeeded the KGB in the country) even warned opposition leaders that a crackdown had been ordered to take place, and several high-ranking officers successfully urged the commander in charge of operations against the protesters to scale back the military assault (Chivers 2005).

The subset of non-violent cases is also increasingly likely to sow the seeds for successful democratic transitions. The average 5-year change in Polity scores for states where campaigns have been non-violent is 7.22 [SD: 6.12]. ${ }^{10}$ In states with violent unrest, this change is a miniscule 0.92 (SD: $5.10)$. Democratization, in spite of the difficulties associated with transition, heralds the arrival of institutions that increase respect for the rule of law and the protection of property. The market is known to respond favorably to these conditions, primarily because they reduce uncertainty over the security of (and returns on) investments (Jensen 2008).

For example, after Zambian president Frederick Chiluba announced his intention to run for a third (and unconstitutional) term in office, citizens amassed in non-violent protests across the country. These protests, alongside additional pressures, including the threat of impeachment by the legislature, ultimately resulted in Chiluba resigning from the presidency. This precipitated broad-ranging democratic reforms. Following Chiluba's ouster, FDI as a proportion of Zambia's GDP rose from approximately $2 \%$ in 2001 to just over $8 \%$ in 2002 and continues to range between $5 \%$ and $11 \%$ to the present, while the country continues to develop more democratic institutions.

Non-violent campaigns therefore exhibit a number of traits that ought to assuage investors' apprehensions over the stability and safety of the market. Non-violent campaigns enjoy wider-spread support. This support, in

\footnotetext{
${ }^{10}$ Polity scores are located on a 20-point scale from -10 (most autocratic) to 10 (most democratic).
}

turn, is an important determinant of the likelihood of a successful outcome and, in some cases, democratization. The result of these campaigns ought to be more political stability. Or, in cases where they precipitate additional reforms, these reforms ought to result in a shift toward the kind of policy environment conducive to FDI-namely, democratic institutions and processes that enhance stability. As a result, international investors perceive less risk in markets where unrest is nonviolent.

H2. FDI flows are lower into states experiencing a period of violent unrest than into states experiencing a period of non-violent unrest.

What are the Long-Term Effects of Unrest?

In this paper, we are interested in more than the immediate effects unrest has on the market. Political instability's costs are not confined to years of unrest. Rather, unrest can leave a lasting legacy on the market, dampening investment flows long after hostilities end. We argue that post-unrest investment levels are shaped by campaign outcomes, which have important consequences for longer term stability.

As emphasized, the relative attractiveness of non-violent campaigns to potential participants means that non-violent campaigns are significantly more likely to end in success - that is, the achievement of the campaign's stated aims (DeNardo 1985; Weinstein 2007; Chenoweth and Stephan 2011). These aims vary significantly and may include regime change, secession, or a myriad other political and/or social reforms. Instinctively, undergoing such reforms may signal additional instability to the market, depressing rather than promoting inward investment. Indeed, many theories of long-term investments (such as FDI) emphasize the importance of policy consistency over rapid and large-scale change. Stable political climates foster investment, even if these climates are non-democratic. ${ }^{11}$ This kind of logic suggests that campaigns that successfully bring about significant policy changes increase uncertainty and deter FDI.

However, there are two reasons to think that successful campaigns leave a less damaging long-term legacy on the market than do unsuccessful campaigns. First, recent work on political institutions and FDI suggests that, in fact, investors favor democratic environments even if they carry with them some risk of reform (Jensen et al. 2012; Jensen 2008). As mentioned, these institutions are associated with traits firms desire: support for the rule of law, the protection of property rights, and comparatively more predictable policy reforms when regime change does occur (Feng 2001). Increased transparency in the political system, as opposed to autocratic regimes, means that the market better anticipates policy changes that affect the returns on investments. Evidence supports this claim; successful political reforms result in higher levels of inward FDI (Brada, Kutan, and Yigit 2006).

Across our sample, 62 campaigns ended successfully and 78 ended unsuccessfully. The average 5-year change in the democracy score (using Polity) of states with cam-

11 One implication is that autocratic regimes can be as attractive, if not more attractive, than democratic regimes where uncertainty over electoral outcomes-and any subsequent reforms-generates risk in the marketplace (Oneal 1994; Li and Resnick 2003). 
paigns that ended successfully is 6.05 [SD: 6.30]. Compare that to the average change in democracy for states with unsuccessful campaigns of 3.07 [SD: 6.33]. ${ }^{12}$ While these statistics do not capture the precise cost of transitions, they reinforce a straightforward logic: states where campaigns are successful become more democratic. This pattern holds almost by definition since most of these movements $(75 \%)$ are directed toward achieving regime change.

Second, and more simply, successful campaigns are less likely to precipitate additional unrest. Even if the reform process is costly, the prospects for additional unrest decrease over time. Approximately $35 \%$ of states experience renewed unrest within 5 years of a failed campaign. The proportion of states relapsing into unrest is slightly lower for successful campaigns (32\%) in the short-term. However, this difference becomes more substantial over time. Looking at the period of 10 years after the end of unrest, $61 \%$ of states with unsuccessful campaigns relapse, compared to $54 \%$ of successful ones. ${ }^{13}$

Crucially, it is not just whether a state relapses into another period of unrest. The nature of this renewed conflict is even more revealing. There is renewed violence in the wake of successful campaigns roughly $50 \%$ of the time (within 5 years). Conversely, violence breaks out nearly $80 \%$ of the time in those cases in which there was previously an unsuccessful campaign. So while there is a non-negligible chance of unrest in both cases-we know that many states experienced multiple periods of unrest in recent history-the nature of this unrest varies.

This variation is important. Unsuccessful campaigns are much more likely to result in a continued cycle of unrest-one that can afflict the market for many years into the future. Success, on the other hand, leads to comparatively more stability. And, even where there are costs associated with reform, these reforms ought to create conditions more conducive to investment. Given these reasons, we expect that successful campaigns are significantly less likely to affect longer term FDI flows than their unsuccessful counterparts.

H3. In the years following unrest, FDI flows are lower into states where campaigns have been unsuccessful than into states where campaigns have been successful.

Our theory identifies an additional benefit of nonviolent tactics. Namely, non-violence has a far less deleterious effect on the market. However, we recognize that there may be plausible alternatives to our hypotheses. For example, non-violent campaigns may actually dampen FDI more than violent ones precisely because these movements tend to be larger (as stated above). Larger campaigns may be more disruptive even if they do not do result in physical harm to individuals or the productive capacity of the economy. Moreover, while non-violence increases the likelihood of success, we have acknowledged that successful outcomes may themselves generate additional political turmoil. Success does not guarantee peace. We have cast doubt on both of these alternative

\footnotetext{
${ }^{12}$ The comparison is even more stark over a 10 -year period. States with successful campaigns enjoy an 8.01-point increase, on average, relative to the 4.26-point increase for states with unsuccessful campaigns.

${ }^{13}$ This difference varies based on how one treats campaigns with mixed or "limited" success. If we instead treat limited successes as failures we observe an even greater disparity $-64 \%$ for failures and $52 \%$ for successes.
}

explanations in this section. Notwithstanding our claims, the effects of tactics and outcomes on FDI remains an open empirical question. To account for these competing expectations we control for both of these alternatives in the analyses below.

\section{Research Design}

This paper explores two related processes. First, we investigate the differential impacts of violent and nonviolent tactics on levels of FDI flows during periods of unrest. Second, we analyze the longer-term effects of different campaign outcomes on investment levels after campaigns end. Before presenting our sequence of tests, we describe our data and how we operationalize our concepts.

\section{Data and Variables}

To test our hypotheses, we construct a dataset on foreign direct investment flows and political unrest across all countries from 1975 to 2010. The data includes one observation for each country $i$ in each year $t$. There are 140 individual periods of unrest - that is, campaigns - in the data set. These 140 periods total roughly 800 of our approximately 7,000 country-year observations, or $11 \%$ of the sample. These campaigns are divided nearly evenly between those that employed predominantly violent tactics $(46 \%)$ and those that employed predominantly nonviolent tactics (54\%). The sample is also distributed widely across regions of the world. ${ }^{14}$

Note that the sample is defined by countries that receive foreign aid (measured as official development assistance from the Development Assistance Committee). We restrict the sample because the primary form of FDI - vertical-that flows into developing countries differs from that of developing countries. As a result, the behavior of the market can reasonably be expected to differ. ${ }^{15}$

\section{Dependent Variables}

This paper explores the effect of political unrest on inward FDI. The dependent variable is total FDI flows into a country $i$ in year $t$. For this data we rely on the World Bank's World Development Indicators. The measure, $F D I_{i, t}$ is measured in constant year 2000 U.S. dollars and divided by GDP. ${ }^{16}$

\section{Independent Variables}

Our tests employ several independent variables relating to the occurrence (and nature) of political unrest. These measures derive primarily from recent work by Chenoweth and Stephan (2011) on campaigns of civil resistance. In the first half of our analysis, we are interested

\footnotetext{
${ }^{14}$ There are 13 cases in the Middle East (9\%), 31 in Asia (22\%), 46 in Africa $(33 \%)$, and 20 in the Americas (14\%). The remaining 30 occurred across Europe and the former Soviet Union.

15 In practice, this restriction does not eliminate any periods of unrest from the data. It simply limits the countries in the reference category (no unrest) to more comparable markets.

${ }^{16}$ All of our reported models use FDI as measured in yearly levels. Note that our baseline results are robust to the use of the 3- and 5-year moving averages of FDI. Moving averages are one way to look trends in investment levels over time. However, the market may adjust quite quickly to the onset of unrest (or any other shocks) and therefore looking at yearly levels is more precise.
} 
in whether unrest deters FDI during the course of the campaign. We operationalize unrest using several measures. First, we look at the effects of political unrest broadly defined. We construct a dichotomous indicator of political unrest that is coded as " 1 " for every countryyear in which a campaign was ongoing. This measure, Unrest $_{i, t}$, allows us to identify whether the occurrence of any type of unrest deters FDI.

However, this broad measure masks the potentially important nature of the tactics employed in each campaign. Our theory predicts that violence leads to greater reductions in foreign investment. To test this proposition, we disaggregate unrest. We create two dichotomous indicators; Violent $t_{i, t}$ is coded " 1 " for every year that a campaign was characterized predominantly by violence and Non-Violent $_{i, t}$ is coded a " 1 " where campaigns were predominantly non-violent. Both of these variables are coded as " 0 " in years with no ongoing campaign of that tactical type.

The second half of our analysis looks at the legacy that unrest leaves on the market. The theory states that the successful resolution of a campaign, since it is associated with greater long-term stability, encourages comparatively greater inflows of FDI. The principal explanatory variable in these models is Success $_{i, t}$, which indicates whether a conflict ended with the campaign achieving its aims. ${ }^{17}$

Before describing the control variables, note that patterns in FDI and political unrest do not overlap-as detailed in Figure 1. The two indicators are loosely and negatively correlated $(-12 \%)$. This is because average FDI inflows have increased steadily since the mid-1990s. However, the peak of unrest in our sample is around the dissolution of the Soviet Union, at least 5 years before the most significant rise in FDI occurs. These patterns are what we would expect; FDI increases in the wake of turmoil in the 1980s.

\section{Control Variables}

We include several country-level predictors of FDI flows that may confound our estimates if omitted. The first is the level of economic development, which ought to be positively correlated with levels of FDI. Development level is measured as logged annual income per capita

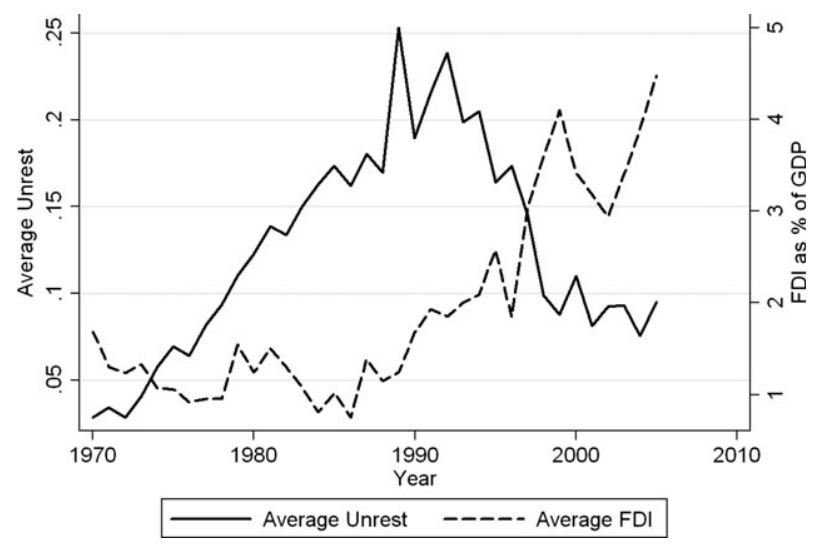

FIG 1. Trends in Political Unrest and FDI Flows

\footnotetext{
17 Since several countries experience multiple campaigns we control for whether they have a history of mixed outcomes (see below).
}

$\left(\right.$ Income $\left._{i . t}\right)$. Second, we include a dichotomous indicator of regime type. Democracies are known to exhibit higher levels of economic openness and to receive larger inflows of investment than their autocratic counterparts. We measure democracy using the dichotomous coding

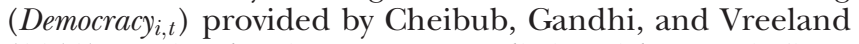
(2010). It is also important to distinguish FDI inflows from other forms of inward capital, including foreign development assistance. We include a measure Aid $_{i, t}$ that is the total annual inflows of official development assistance received by each state as a \% of GDP.

Three other indicators of broader market activity and regulation are likely to be associated with FDI levels. The first is Trade $_{i, t}$, which we measure as total exports plus imports as a percentage of GDP. Trade data is collected from the UN's COMTRADE database and growth can be

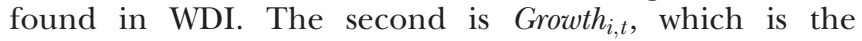
annual percentage change in GDP. We also include a

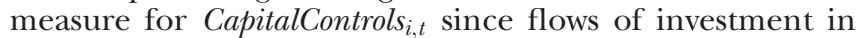
and out of a country are shaped fundamentally by the existence of restrictions on the free movement of capital. We use the Chinn-Ito Index of capital account openness (Chinn and Ito 2008). All three of these measures should be positively correlated with inward FDI flows.

The models also contain variables designed to address some of the problems commonly associated with pooled panel data. For example, FDI exhibits a high degree of temporal correlation; investment levels in year $t-1$ are a powerful predictor of levels in year $t$. To correct for this time trend, we include a lagged dependent variable $\left(F D I_{i, t-1}\right)$.

Moreover, our country-year unit of observation is problematic in the few instances in which there are multiple campaigns occurring simultaneously. Campaigns coincide in only $6 \%$ of the total number of observations in our sample. However, it is important to ensure that we take this overlap into account when running our estimations. We correct for this issue in two ways. First, we have run our estimations separately on samples using only the longest (in duration of years) and largest (in number of participants) campaigns. This paper reports only those models that include the longest campaigns. However, the findings are consistent when using the alternative approach. ${ }^{18}$ Second, even when restricting the sample, it is important to control for the occurrence of simultaneous conflicts. We include a variable that flags countryyears when there are multiple ongoing campaigns (MultipleCampaigns ${ }_{i, t}$ ).

Finally, the sensitivity of investors to risk is based in part on their demand for the rule of law. Unfortunately, many indicators of rule of law suffer from limited temporal or country coverage. To our knowledge, the most promising candidate measure is available in the World Bank's World Governance Indicators. Their rule of law measure covers most of the world from 1996-2010. However, this still severely restricts our sample (by as much as $90 \%$ in our baseline models). Therefore we omit this variable, RuleofLaw $w_{i, t}$, from our main analysis.

Descriptive statistics for all of our covariates can be found in Table 1.

\section{Analysis and Results}

To test the validity of our hypotheses, we present a sequence of tests that address two related questions.

\footnotetext{
${ }^{18}$ The number of observations affected by the sampling restrictions is small and the estimates from the two samples are nearly identical.
} 
TABLe 1. Descriptive Statistics

\begin{tabular}{lrccc}
\hline Variables & Mean & Standard Deviation & Minimum & Maximum \\
\hline FDI $_{i, t}$ & 2.60 & 4.75 & -82.81 & 43.82 \\
Unrest $_{i, t}$ & 0.11 & 0.32 & 0 & 1 \\
Violent $_{i, t}$ & 0.08 & 0.28 & 0 & 1 \\
Non-violent $_{i, t}$ & 0.02 & 0.16 & 0 & 1 \\
Success $_{i, t}$ & 0.45 & 0.49 & 0 & 1 \\
Income $_{i, t}$ & 7.29 & 1.41 & 4.05 & 11.6 \\
Democracy $_{i, t}$ & 0.38 & 0.49 & 0 & 1 \\
Aidd $_{i, t}$ & 0.13 & 0.19 & -0.02 & 2.77 \\
Trade $_{i, t}$ & 0.78 & 1.41 & 0 & 48.73 \\
Growth $_{i, t}$ & 3.77 & 6.66 & -51.03 & 106.28 \\
CapitalControls $_{i, t}$ & -0.21 & 1.44 & -1.81 & 2.53 \\
MultipleCampaigns $_{i, t}$ & 0.01 & 0.08 & 0 & 1 \\
${\text { Rule of } \text { Law }_{i, t}}_{\text {Stability }_{i, t}}$ & 0.06 & 1.02 & -2.04 & 2.12 \\
Fractionalization $_{i, t}$ & 12.40 & 12.57 & 0 & 41 \\
InfantMortality $_{i, t}$ & 0.47 & 0.25 & 0 & 0.93 \\
Pral & 63.49 & 46.89 & 2.30 & 284.78 \\
\hline
\end{tabular}

First, we investigate whether the occurrence of unrest deters inward FDI (Models 1-5). We find that unrest is moderately associated with reduced capital flows. When we look closer at the nature of each conflict, however, we find that the relationship is driven exclusively by those campaigns that adopt predominately violent tactics. The findings indicate that violence is strongly associated with reductions in investment during the course of the campaign. Conversely, periods of non-violent unrest have no discernible (statistically significant) effect on investment.

Second, we explore the longer term effects of unrest on the health of the market (Models 6-8). We find that unrest has the potential to generate high opportunity costs. However, a history of violence does not independently impact post-conflict FDI flows. Instead, states' economic trajectories are shaped by whether or not campaigns successfully achieve their aims. States with campaigns that result in a successful outcome are far less likely to experience a reduction in investment-regardless of the predominant tactics - than are states with unsuccessful campaigns.

\section{Models 1-7: Does Unrest Deter FDI?}

Our theory predicts that FDI flows are lower into countries experiencing political unrest than in their more stable counterparts. A Wooldridge test rejects the null hypothesis of no autocorrelation $(F=61.44)$ and a Breusch-Pagan test confirms the presence of heteroskedasticity $(p<.000)$. Given the traits exhibited by our data we use panel-corrected standard errors with a lagged dependent variable. ${ }^{19}$ This method produces more precise standard errors. The model equation takes on the following specification:

$$
F D I_{i, t}=\beta_{0}+\beta_{1} \text { Unrest }_{i, t}+\beta_{2} Z_{i, t}+\alpha_{i}+\mu_{i, t}
$$

where $Z_{i, t}$ represents a vector of controls, and $\mu_{i, t}$ is the panel-corrected error term.

Model 1 provides a good overall fit to the data ( Table 2). The $R^{2}$ is 0.44 and there is no evidence that multicollinearity biases the estimates (none of the covariates are correlated at more than 54\%). The controls

\footnotetext{
19 The results remain the same when using an AR.1 process to correct for time dependence rather than the lagged DV.
}

behave largely as expected, which builds our confidence in the model specification. Lagged FDI is naturally a strong predictor of investment in year $t$. States with more open capital accounts and richer nations also enjoy comparatively larger inflows of FDI. And, importantly, democracies receive larger inflows of foreign capital, supporting the logic that investors respond favorably to democratic institutions.

Turning to our explanatory variable, the coefficient on Unrest $_{i, t}$ is negative and significant, suggesting that periods of domestic political unrest have a dampening effect on FDI. The substantive effects are illustrated in Figure 2. Unrest is associated with a $15 \%$ drop in investment, or a decrease from $2.78 \%$ of GDP [2.57, 2.99] to $2.36[2.04,2.69] .{ }^{20}$ This drop suggests that there is a significant opportunity cost associated with unrest. Domestic markets undergoing periods of unrest are comparatively less attractive investment opportunities for foreign investors.

However, Unrest $_{i, t}$ masks the precise nature of the conflict. Our theory predicts that violence ought to have a uniquely powerful dampening effect on FDI. Violent conflicts suggest greater unrest to the market in both the short- and long-term. Periods of unrest last four times longer on average when the predominant tactics are violent. $^{21}$ Moreover, only $27 \%$ of violent campaigns end in success, whilst nearly $60 \%$ of nonviolent campaigns end successfully.

In light of these patterns, the market should be wary of economies marred by violent unrest. In Model 2, we explore this relationship by using our disaggregated measures of violence and non-violence (Table 2). ${ }^{22}$ Model 2 reveals that the relationship between unrest and FDI is driven entirely by the use of violence. States afflicted by violent unrest experience a $17 \%$ decrease in FDI from $2.78[2.57,2.99]$ to 2.29 [1.94, 2.64]. The presence of non-violent unrest, to the contrary, has no discernible effect on investment. Non-violent unrest results in a comparatively negligible 5\% drop in FDI from the same baseline of $2.78[2.57,2.99]$ to 2.68 [2.15, 3.07]. Thus, violence has a substantial effect on market outcomes; investors are far more likely to avoid economies afflicted by violent unrest.

The findings provide insights into the sometimes ambiguous relationships between political unrest and market outcomes. The null result for non-violence suggests that the market is not sensitive to the occurrence of unrest broadly defined. Instead, each campaign's chosen tactics matter a great deal. Only when events turn violent does the market appear to respond.

We subject these findings to a variety of robustness checks. To begin with, Model 3 employs an AR.1 process rather than the lagged dependent variable to correct for time dependence. Model 4 includes the WGI measure for rule of law. As mentioned above, this variable hugely truncates our sample. However, the results are consistent in both of these specifications (Table 2).

Moreover, the relationship between unrest and FDI may be shaped by each campaign's political aims. The sample varies with respect to the underlying causes of

\footnotetext{
${ }^{20}$ Brackets report the $95 \%$ confidence interval.

${ }^{21}$ Violent campaigns last an average of 7.88 years while non-violent campaigns only last an average of 1.79 years.

${ }^{22}$ Using both indicators in the same equation ensures that the reference category is years of no unrest. Therefore, we get a direct comparison of the impacts of violent and non-violent campaigns on FDI relative to that of peace.
} 
TABLE 2. Does Unrest Deter FDI?

\begin{tabular}{|c|c|c|c|c|c|}
\hline $\begin{array}{l}\text { Model } \\
\text { Variables }\end{array}$ & $\begin{array}{c}(1) \\
\text { Unrest }_{i, t} \\
\text { PCSE }\end{array}$ & $\begin{array}{c}\text { (2) } \\
\text { Violent }_{i, t} \\
\text { PCSE }\end{array}$ & $\begin{array}{c}(3) \\
\text { Violent }_{i, t} \\
\text { AR.1 }\end{array}$ & $\begin{array}{c}(4) \\
\text { Violent }_{i, t} \\
w / R O L\end{array}$ & $\begin{array}{c}\text { (5) } \\
\text { Violent }_{i, t} \\
\text { w/aims }\end{array}$ \\
\hline Unrest $_{i, t}$ & $-0.418(0.159)^{* *}$ & & & & \\
\hline Violent $_{i, t}$ & & $-0.490(0.176)^{* *}$ & $-0.799(0.383) *$ & $-2.011(0.840) *$ & $-0.781(0.253) * *$ \\
\hline Non-violent ${ }_{i, t}$ & & $-0.169(0.224)$ & $-0.343(0.259)$ & $-0.685(0.892)$ & $-0.460(0.257)$ \\
\hline RegimeChange $_{i, t}$ & & & & & $0.630(0.205)^{* *}$ \\
\hline Self-Determination $_{i, t}$ & & & & & $0.186(0.330)$ \\
\hline Secession $_{i, t}$ & & & & & $0.175(0.287)$ \\
\hline Income $_{i, t}$ & $0.217(0.066)^{* *}$ & $0.213(0.066)^{* *}$ & $0.433(0.162) * *$ & $0.437(0.284)$ & $-0.017(0.129)$ \\
\hline Democracy $_{i, t}$ & $0.269(0.106)^{* *}$ & $0.275(0.106)^{* *}$ & $0.492(0.269)$ & $0.058(0.676)$ & $0.032(0.160)$ \\
\hline $\operatorname{Aid}_{i, t}$ & $-0.057(0.584)$ & $-0.067(0.584)$ & $-1.147(1.270)$ & $-1.337(2.835)$ & $-1.295(1.538)$ \\
\hline Trade $_{i, t}$ & $-0.285(0.183)$ & $-0.283(0.183)$ & $0.017(0.384)$ & $-1.960(0.312)^{* *}$ & $-0.372(0.225)^{*}$ \\
\hline Growth $_{i, t}$ & $0.010(0.016)$ & $0.010(0.016)$ & $-0.001(0.012)$ & $0.037(0.063)$ & $-0.018(0.031)$ \\
\hline CapitalControls $_{i, t}$ & $0.143(0.055)^{*}$ & $0.142(0.056)^{* *}$ & $0.307(0.117)^{* * *}$ & $0.065(0.170)$ & $0.218(0.097)^{*}$ \\
\hline$F D I_{i, t-1}$ & $0.616(0.045)^{* *}$ & $0.616(0.045)^{* *}$ & & $0.478(0.096)^{* *}$ & $0.480(0.094)^{* *}$ \\
\hline MultipleCampaigns $_{i, t}$ & $-0.224(0.242)$ & $-0.212(0.243)$ & $-0.184(0.279)$ & & $-0.360(0.272)$ \\
\hline Rule of $L a w_{i, t}$ & & & & $0.882(0.267) * *$ & \\
\hline Constant & $-0.281(0.516)$ & $-0.251(0.516)$ & $-0.175(1.219)$ & $0.512(2.403)$ & $1.624(1.108)$ \\
\hline Observations & 3,973 & 3,973 & 4,022 & 320 & 1,580 \\
\hline$R^{2}$ & .44 & .44 & .03 & .67 & .35 \\
\hline
\end{tabular}

Panel-corrected standard errors in parentheses $* p<.05, * * p<.001$.

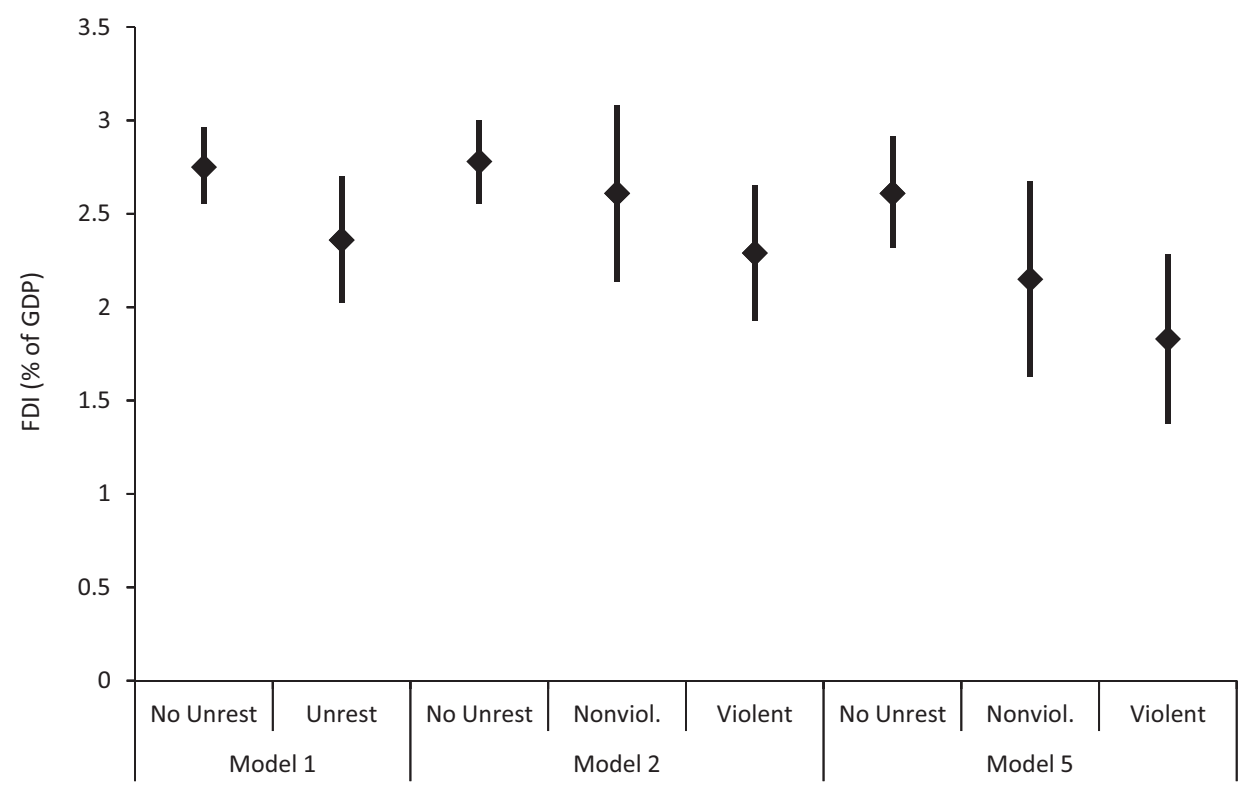

FIg 2. Substantive Effects

unrest. The vast majority of campaigns concern regime change $(75 \%)$. However, there are also a number of campaigns motivated by a desire for secession (14\%) and selfdetermination $(8 \%)$. It is possible that certain motivations are perceived to be more or less disruptive to the market. As stated above, many of these aims are likely to lead to additional turmoil during periods of reform. To control for this possibility, we introduce dichotomous indicators for each of these different aims in Model 5 (Table 2). ${ }^{23}$ We find that they do not affect the substantive interpretation of the baseline results (Figure 2). ${ }^{24}$

\footnotetext{
23 This leaves "other" aims as our omitted category.

${ }^{24}$ The results are actually strong when controlling for campaign aims. Predicted FDI flows into countries experiencing violent unrest are $30 \%$ lower, falling from $2.61[2.33,2.89]$ to 1.83 [1.39, 2.27].
}

Notice that the only aim with a significant result is regime change. Campaigns directed toward regime change receive comparatively larger inflows of FDI. This provides support for the intuition that domestic political reforms - specifically, moves toward democratization-are viewed favorably by the market. From Model 5 we conclude that violence has a strong independent effect on FDI even when controlling for the political motivations of each campaign.

Our results may also be contaminated by selection bias. States select themselves into unrest non-randomly. Failing to correct for this selection process may lead to false inferences. We estimate a Heckman selection model designed to correct for this bias. The selection equation predicts whether a country experiences unrest. The outcome equation then predicts FDI flows. 
The selection equation relies on a number of measures to ensure that the system is identified properly. ${ }^{25}$ Specifically, The probability of unrest should likewise increase in the social stratification of society. We include an indicator of ethnic Fractionalization $_{i, t}$, which is designed to capture socioeconomic cleavages that may lead to (or create conditions conducive to) unrest. Overall levels of poverty, not just the inequality level, may also affect the likelihood of unrest. To capture levels of poverty, we include a measure of InfantMortality $i, t$, which is the number of deaths per 1,000 children.

The selection equation also includes our measures of income and regime type since both wealth and democratic institutions shape the likelihood that unrest occurs. Finally, we include a simple count of the number of years of Stability $_{i, t}$ that preceded the outbreak of unrest. ${ }^{26}$ The system of equations is structured as follows, with the selection equation written as:

$$
\begin{aligned}
\text { Unrest }_{i, t} & =\beta_{0}+\beta_{1} \text { Fractionalization }_{i, t-1}+\beta_{2} \text { InfantMortality }_{i, t-1} \\
& +\beta_{3} \text { Stability }_{i, t-1}+\beta_{4} \text { Income }_{i, t-1}+\beta_{5} \text { Democracy }_{i, t-1} \\
& +\beta_{6} \text { FDI }_{i, t-1}+\eta_{i, t}
\end{aligned}
$$

where all of the right-hand side variables are lagged one year and $\eta_{i, t}$ represents the error term. The outcome equation is the same as that specified above in Model 1:

$$
\begin{aligned}
F_{i, t} & =\beta_{0}+\beta_{1} \text { Income }_{i, t}+\beta_{2} \text { Democracy }_{i, t}+\beta_{3} \text { PTA }_{i, t} \\
& +\beta_{4} \text { FDI }_{i, t-1}+\beta_{5} \text { MultipleCampaigns } i_{i, t}+\mu_{i, t}
\end{aligned}
$$

Before discussing the full selection model, we report the selection equation separately to clarify its performance. Model 6 in Table 3 is a simple probit model with robust standard errors designed to ensure that we are predicting unrest effectively in the selection stage. The model provides a good overall fit to the data. Richer countries, democracies, and those experiencing longer periods of stability are all significantly less likely to experience unrest.

The Model 7 estimates the full Heckman (Table 3). First, note that the chi-squared statistic is $5.72(p<.016)$, which justifies taking a closer look at selection effects. More generally, the model provides a good overall fit to the data. In the selection equation, previous FDI inflows, income, democracy, and the length of time states have been stable are all negatively associated with unrest. In the outcome equation, the results echo the baseline estimates in Model 2. Violence is negatively and significantly related to FDI inflows during the years of ongoing instability. Violent campaigns lead to a $13 \%$ reduction in FDI once correcting for non-random selection into unrest. This represents only a modest decrease in the effect reported in Model 2.

The findings provide strong support for H2. While there appears to be an association between unrest and FDI (H1), further investigation reveals that violence has a strong, independent effect on market outcomes. Investors are wary of economies characterized by high levels of uncertainty. Uncertainty is greater for markets where domestic political unrest is violent. Thus, these economies receive comparatively lower levels of FDI.

\footnotetext{
${ }^{25}$ Heckman models are weakly identified based on assumptions about similarity in the distributions of the dependent variables. This assumption is not often met in practice. Consequently, we introduce several variables that ought to be strong predictors of unrest and weak predictors of FDI.

\begin{tabular}{|c|c|c|c|}
\hline \multirow{2}{*}{$\begin{array}{l}\text { Model } \\
\text { Variables }\end{array}$} & \multirow{2}{*}{$\frac{(6)}{\text { Unrest }_{i, t}}$} & \multicolumn{2}{|l|}{ (7) } \\
\hline & & Unrest $_{i, t}$ & $F D I_{i, t}$ \\
\hline Violent $_{i, t}$ & & & $\begin{array}{l}-1.532 \\
(0.722)^{*}\end{array}$ \\
\hline Fractionalization $_{i, t-1}$ & $\begin{array}{l}-0.367 \\
(0.120) * *\end{array}$ & $\begin{array}{r}-0.156 \\
(0.124)\end{array}$ & \\
\hline InfantMortality $_{i, t-1}$ & $\begin{array}{c}-0.001 \\
(0.001)\end{array}$ & $\begin{array}{c}0.001 \\
(0.001)\end{array}$ & \\
\hline Stability $_{i, t-1}$ & $\begin{array}{l}-0.066 \\
(0.005) * *\end{array}$ & $\begin{array}{l}-0.054 \\
(0.011) * *\end{array}$ & \\
\hline Income $_{i, t-1}$ & $\begin{array}{l}-0.181 \\
(0.030) * *\end{array}$ & $\begin{array}{l}-0.163 \\
(0.033) * *\end{array}$ & $\begin{array}{r}0.214 \\
(0.257)\end{array}$ \\
\hline Democracy $_{i, t-1}$ & $\begin{array}{l}-0.290 \\
(0.066) * *\end{array}$ & $\begin{array}{l}-0.165 \\
(0.073) *\end{array}$ & $\begin{array}{r}0.155 \\
(0.337)\end{array}$ \\
\hline$F D I_{i, t-1}$ & $\begin{array}{l}-0.039 \\
(0.014) * *\end{array}$ & $\begin{array}{c}-0.028 \\
(0.012) *\end{array}$ & $\begin{array}{c}0.881 \\
(0.373) *\end{array}$ \\
\hline $\operatorname{Aid}_{i, t}$ & & & $\begin{array}{l}-3.091 \\
(2.491)\end{array}$ \\
\hline Trade $_{i, t}$ & & & $\begin{array}{l}-0.211 \\
(0.199)\end{array}$ \\
\hline Growth $_{i, t}$ & & & $\begin{array}{l}-0.065 \\
(0.053)\end{array}$ \\
\hline CapitalControls $_{i, t}$ & & & $\begin{array}{l}-0.012 \\
(0.127)\end{array}$ \\
\hline MultipleCampaigns $_{i, t}$ & & & $\begin{array}{l}-0.790 \\
(0.400)^{*}\end{array}$ \\
\hline Constant & $0.983(0.258)^{* *}$ & $0.517(0.325)$ & $\begin{array}{c}6.215 \\
(2.940)^{*}\end{array}$ \\
\hline Observations & 4,309 & 4,232 & \\
\hline
\end{tabular}

${ }^{26}$ We also ran models using polynomial terms-Stability $y_{i, t}$ squared and cubed - to account for temporal dependence and the results remained consistent.
}

TABLE 3. Does Unrest Deter FDI?

Standard errors in parentheses $* p<.10, * * p<.05, * * * p<.001$.

Importantly, this result is not contingent on the nature of the political aims of the campaigns. Nor is it an artifact of how states "select" themselves into periods of unrest. By implication, further investigations of political unrest's effects on the market must take variation in campaign tactics into account.

\section{Models 8-10: What are the Long-Term Effects of Unrest?}

The baseline estimates show that violence deters FDI during the years instability is ongoing. However, unrest's opportunity costs likely extend beyond the duration of the campaign. In this section, we explore the lasting effects that unrest has on the market.

The theory predicts that post-unrest investment flows are determined in large part by how campaigns end. Specifically, when campaigns end successfully, the resulting political climate is comparatively more stable. Consequently, we ought to observe higher levels of FDI into states where unrest came to a successful conclusion.

We start by looking at the association between violence and FDI. Since violence dampens capital flows during periods of unrest it may also leave a lasting impression on the market, particularly given that it is strongly associated with success. Model 8 tests the proposition that a history of violence-defined as whether or not past campaigns used violent tactics - deters FDI in the years after unrest has concluded. Note that we again rely on Heckman selection models for the tests in this section. There are theoretical and econometric reasons for this. First, the long-term effects of violence (or success) on FDI are likely to be shaped by the very same factors that predispose 
TABLE 4 . What are the long-term effects of unrest?

\begin{tabular}{|c|c|c|c|c|c|c|}
\hline \multirow{2}{*}{$\begin{array}{l}\text { Model } \\
\text { Variables }\end{array}$} & \multicolumn{2}{|c|}{ (8) } & \multicolumn{2}{|c|}{ (9) } & \multicolumn{2}{|c|}{ (10) } \\
\hline & Unrest $_{i, t}$ & $F D I_{i, t}$ & Unrest $_{i, t}$ & $F D I_{i, t}$ & Violent $_{i, t}$ & $F D I_{i, t}$ \\
\hline Violent $_{i, t}$ & & $-0.016(0.157)$ & & & & \\
\hline Success $_{i, t}$ & & & & $0.660(0.176)^{* *}$ & & $0.439(0.188)^{*}$ \\
\hline Fractionalization $_{i, t-1}$ & $1.561(0.203)^{* *}$ & & $1.559(0.203)^{* *}$ & & $-0.156(0.098)$ & \\
\hline InfantMortality $_{i, t-1}$ & $-0.023(0.002)^{* *}$ & & $-0.023(0.002) * *$ & & $0.004(0.001)^{* *}$ & \\
\hline Stability $_{i, t-1}$ & $-0.278(0.014) * *$ & & $-0.278(0.014) * *$ & & $0.010(0.005)^{*}$ & \\
\hline Income $_{i, t-1}$ & $-0.653(0.061) * *$ & $0.122(0.087)$ & $-0.652(0.061) * *$ & $0.075(0.084)$ & $-0.096(0.037) *$ & $-0.499(0.132)^{* *}$ \\
\hline Democracy $_{i, t-1}$ & $0.688(0.104)^{* *}$ & $-0.136(0.176)$ & $0.686(0.104)^{* *}$ & $-0.175(0.175)$ & $-0.519(0.071) * *$ & $-1.409(0.262)^{* *}$ \\
\hline$F D I_{i, t-1}$ & $0.040(0.006)^{* *}$ & $0.357(0.090)^{* *}$ & $0.040(0.006)^{* *}$ & $0.348(0.090)^{* *}$ & $0.035(0.015)^{*}$ & $0.309(0.069)^{* *}$ \\
\hline$A i d_{i, t}$ & & $1.355(0.916)$ & & $1.326(0.890)$ & & $0.900(0.542)$ \\
\hline Trade $_{i, t}$ & & $-0.002(0.389)$ & & $0.039(0.391)$ & & $-0.214(0.150)$ \\
\hline Growth $_{i, t}$ & & $0.010(0.022)$ & & $0.015(0.022)$ & & $-0.011(0.016)$ \\
\hline CapitalControls $_{i, t}$ & & $0.429(0.076) * *$ & & $0.403(0.076)^{* *}$ & & $0.242(0.069) * *$ \\
\hline Constant & $6.158(0.527) * *$ & $1.168(0.608)$ & $6.146(0.526)^{* *}$ & $1.197(0.576)^{*}$ & $0.537(0.292)$ & $2.884(0.866)^{* *}$ \\
\hline Observations & \multicolumn{2}{|c|}{3,575} & \multicolumn{2}{|c|}{3,575} & \multicolumn{2}{|c|}{1,102} \\
\hline
\end{tabular}

Standard errors in parentheses $* p<.05, * * p<.001$.

states to unrest in the first place. Second, the chi-squared test statistic in Model 7 is sufficient to suggest that selection effects may be at play. Third, we want to compare the different experiences of states emerging from unrest. In Models 1-5, the reference category was all countryyears, regardless of whether or not there was unrest. Here, we want to know what shapes economic outcomes in only those states with a prior history of domestic political unrest.

Model 8 uses the same specification as outlined above, where the selection equation predicts unrest and the outcome equation predicts FDI flows. However, the sample in the outcome equation is now restricted to years after a period of unrest. Since we are interested in post-unrest FDI the sample does not include observations prior to (or during) active campaigns. Nor does it include any observations from countries that have not experienced unrest at all.

Model 8 finds no evidence that violence has a statistically significant independent effect on post-unrest FDI (see Table 4). The coefficient on Violent $t_{i, t}$ does not approach significance and we cannot conclude that a history of violence per se has a long-term effect on the market. Importantly, this null finding is not inconsistent with our expectations. For the reasons outlined in our theory, we expect that outcomes affect post-unrest FDI more than tactics. While these two traits of each campaign are related, the singular importance of outcomes - that is, success - may overwhelm the independent effect of violence. In other words, what matters to the market is an expectation about whether their investments are vulnerable to conflict renewal.

This is borne out in the real world where countries that experienced horrifying and protracted civil conflict have subsequently seen considerable increases in FDI following the success of violent campaigns. For example, Rwanda experienced impressive post-conflict FDI growth, in spite of the difficulties associated with their history of violence-for example, the high human cost of conflict, the lengthy reconciliation period, etc. Indeed, FDI increased dramatically from $0.2 \%$ of GDP in 1994 to over $2.0 \%$ in the current decade.

Model 9 introduces our indicator of success into the outcome equation. The results show that markets whose campaigns end with successful resolution attract significantly greater levels of inward investment. ${ }^{27}$ Success is associated with an average post-unrest FDI inflow of 3.44 [3.14, 4.74] as compared to 2.78 [2.58, 2.98] for states that experience failure. The mean across the sample of post-unrest years is 2.90 so this 0.7 -point jump in FDI as a \% of GDP represents a significant boost.

Success appears to be a key determinant of a state's capacity to attract FDI in the wake of unrest. The implications are important; when campaigns end unsuccessfully the deleterious effects that unrest has on the market extend beyond the years of political instability. The threat of renewed conflict and, in particular, renewed violence, continues to deter risk-averse investors even if campaigns have come to an end.

Before concluding, we subject this proposition to some additional testing. We have shown that success is a strong predictor of FDI and that violence appears to play a less significant role. However, we have highlighted throughout this paper that tactics and outcomes are closely linked. Specifically, violent campaigns are far less likely, for the variety of reasons discussed above, to achieve their aims than non-violent ones. Moreover, success may not matter for long-term FDI if the preceding campaign was violent. Violence may lead to damaged productive capacity, human capital flight, and a variety of other things that may reduce returns on investments. Thus, even if campaigns are successful, sufficient damage may have already been done to the domestic economy to deter FDI for some time into the future.

Model 10 looks at whether success has a positive effect on post-unrest FDI once adjusting for non-random selection into violence, not just into unrest. The estimates are reported in Table 4 . The results of the outcomes equation are consistent with those produced by Model 9. Successful outcomes result in significantly greater inflows of post-unrest FDI, even in the sub-sample of countries with a history of violence.

To further test the durability of our findings, we controlled for several indicators of stability. We introduced a binary indicator of whether or not a state relapsed into unrest within 5 years of the previous campaign's

\footnotetext{
${ }^{27}$ In some states that have experienced multiple periods of unrest there have been varied outcomes. We controlled for whether there were any past failures and found that the results remain constant.
} 
conclusion. This is a direct measure of whether instability continues to afflict states (and their markets) over time. Moreover, we added a control for the duration of the campaign. This ought to approximate the cost of unrest to the state and economy, assuming that costs are increasing in time. Finally, in separate models we controlled for the difference in Polity scores - that is, the level of democratization-for the 5- and 10-year periods after unrest. In all of these cases, the additional controls were signed correctly. Relapse into subsequent unrest and the duration of each campaign are both negatively associated with FDI. Democratization, conversely, is positively associated with FDI. However, in each of these models our core result remained robustly unchanged.

The evidence supports the claim that outcomes have a significant impact on the long-term consequences of unrest. Markets in states with campaigns that achieve their aims seem to recover their abilities to attract capital. This relationship holds even when the campaign has been marred by violent tactics, which we show dampen FDI during the years of unrest themselves.

\section{Conclusions}

This paper asks two related questions. First, does domestic political unrest deter inward FDI? Second, does unrest leave a lasting impact on the market? We argue that periods of violent unrest signal greater risk to the market than non-violent periods. Violence is associated with a greater likelihood of an unsuccessful outcome to the campaign. Markets are wary of states where campaigns have ended in failure, because although success can be costly in many ways, unsuccessful campaigns often precipitate recurrent cycles of violence. By extension, markets receive less FDI when campaigns are violent and when they are unsuccessful. We find strong evidence in favor of these propositions, even after taking political motivations and non-random selection into account.

The theory and evidence make a number of contributions. First, it provides a theoretically-motivated clarification of the empirical ambiguity in the relationship between unrest and FDI. Previous studies have returned mixed support for the proposition that unrest deters FDI, in spite of investors' supposed aversion to political risk. Here, we show that periods of unrest vary significantly in character and, by extension, the effects they have on market outcomes.

Second, and related, the paper identifies a specific channel through which unrest affects states' welfare. Existing work shows that dampened growth and development are among unrest's various opportunity costs, for example, Collier (1999). We do not test FDI's growthgenerating effects directly in this paper. However, we help specify the conditions under which states are more or less likely to receive investment. This may have important implications for understanding how unrest shapes states' longer-term development trajectories.

Third, the evidence supports the intuition that investors respond to perceptions of markets' future stability. The historical record shows that violent tactics and unsuccessful campaigns tend to signal longer lasting (and repeated) unrest. The differential effects that tactics and outcomes have on FDI flows suggest that investors rely on these signals to inform their decisions about host markets. With this idea in mind, close attention should be paid to the many countries that have experienced political unrest as part of the Arab Spring. This wave of pro- democracy protests and civil wars provides notable variation in both the tactics (non-violent events in Tunisia and Egypt, and violent events in Libya and Syria) and the outcomes (tentatively successful change in Tunisia but not in Bahrain, for instance) of conflict. Thus, the events of the Arab Spring ought to provide a suitable set of test cases for our logic as events continue to clarify themselves.

Fourth, previous work suggests that foreign support plays a crucial role in enabling non-violence (Chenoweth and Stephan 2011). Investors wishing to insulate their capital from risk have clear material incentives to encourage their governments to support non-violent campaigns in countries in which they hold investments or are contemplating investing. Our results do not speak to the role investors might play in the onset or duration of unrest. However, they do show that investors are wary of violence. Firms already operating within markets have strong reasons to promote non-violence when unrest does occur.

Additional avenues for future research remain open. We stressed that a fuller account of how political instability shapes the market must consider variation across different forms of unrest. To that end, we explored how tactics and outcomes condition FDI flows in the shortand long-term. However, these are just two items on a lengthy list of factors that likely inform investors' perceptions of risk. For example, while our results do not provide strong evidence relating to campaigns' political motivations, further research ought to be carried out in this area.

Finally, this paper does not look at variation in investors' own sensitivities to risk. Some investors may thrive on political instability. For the reasons stated above, it is unlikely that this is a widespread phenomenon. However, if at least some investors respond favorably to risk, then FDI may lead to protracted conflicts and do very little to assist in the economic recovery of states. More work has to be done on the relationship between specific industries/sectors and unrest as well as between FDI and duration of unrest.

\section{References}

Agarwal, Jamuna P. (1980) Determinants of Foreign Direct Investment: A Survey. Review of World Economics 116 (4): 739-773.

Aharoni, Yair. (1966) The Foreign Investment Decision Process. Cambridge, MA: Harvard University Press.

Asiedu, Elizabeth. (2006) Foreign Direct Investment in Africa: The Role of Natural Resources, Market size, Government Policy, Institutions and Political Instability. The World Economy 29 (1): 6377.

Banks, Arthur S. (2008) Cross-National Time-Series Data Archive (CNTS) 1815-2007. Jerusalem, Israel: Databanks International.

Barbieri, Katherine AND Rafael Reuveny. (2005) Economic Globalization and Civil War. Journal of Politics 67 (4): 1228-1247.

Bénassy-Quéré, Agnés, Maylis Coupet and Thierry Mayer. (2007) Institutional Determinants of Foreign Direct Investment. The World Economy 30 (5): 764-782.

Bennett, Peter D. And Robert T. Green. (1972) Political Instability as a Determinant of Direct Foreign Investment in Marketing. Journal of Marketing Research 9 (2): 182-186.

Biglaiser, Glen and Karl DeRouen, Jr. (2006) Economic Reforms and Inflows of Foreign Direct Investment in Latin America. Latin American Research Review 41 (1): 51-75.

Brada, Josef C., Ali M. Kutan and Taner M. Yigit. (2006) The Effects of Transition and Political Instability on Foreign Direct Investment Inflows. Economics of Transition 14 (4): 649-680.

Buhaug, Halvard and Kristian S. Gleditsch. (2008) Contagion or Confusion? Why Conflicts Cluster in Space. International Studies Quarterly 52 (2): 215-233. 
Busse, Matthias and Carsten Hefeker. (2007) Political Risk, Institutions and Foreign Direct Investment. European Journal of Political Economy 23 (2): 397-415.

Büthe, Tim and Helen V. Milner. (2008) The Politics of Foreign Direct Investment into Developing Countries: Increasing FDI through International Trade Agreements? American Journal of Political Science 52 (4): 741-762.

Cheibub, Jose A., Jennifer Gandhi, and James R.. Vreeland. (2010) Democracy and Dictatorship Revisited. Public Choice 143 (1): 67-101.

Chenoweth, Erica and Maria J. Stephan. (2011) Why Civil Resistance Works: The Strategic Logic of Nonviolent Conflict. New York: Columbia University Press.

Chinn, Menzie D. And Hiro Ito. (2008) A New Measure of Financial Openness. Journal of Comparative Policy Analysis: Research and Practice 10 (3): 309-322.

Chivers, Christopher J. (2005) A Crackdown Averted: How Top Spies in Ukraine Changed the Nation's Path. The New York Times, June 17.

Collier, Paul. (1999) On the Economic Consequences of Civil War. Oxford Economic Papers 51 (1): 168-183.

Collier, Paul. (2003) Breaking the Conflict Trap: Civil War and Development Policy. Washington: World Bank.

DeNardo, James. (1985) Power in Numbers: The Political Strategy of Protest and Rebellion. Princeton: Princeton University Press.

FenG, YI. (2001) Political Freedom, Political Instability, and Policy Uncertainty: A Study of Political Institutions and Private Investment in Developing Countries. International Studies Quarterly 45 (2): 271294.

Gleditsch, Nils P., Peter Wallensteen, Michael Eriksson, Margareta Sollenberg, and Hävard Strand. (2002) Armed Conflict 1946-2001: A New Dataset. Journal of Peace Research 39 (5): 615-637.

Greene, Thomas H. and Joseph LaPalombara. (1974) Comparative Revolutionary Movements. Englewood Cliffs, NJ: Prentice-Hall.

Habib, Mohsin and Leon Zurawicki. (2002) Corruption and Foreign Direct Investment. Journal of International Business Studies 33 (2): 291-307.

Hegre, Hävard, Tonya Ellingsen, Scott Gates, and Nils P. Gleditsch. (2001) Toward a Democratic Civil Peace? Democracy, Political Change, and Civil War, 1816-1992? American Political Science Review 95 (1): 33-48.

Jensen, Nathan. (2008) Political Risk, Democratic Institutions, and Foreign Direct Investment. The Journal of Politics 70 (4): 1040-1052.

Jensen, Nathan, Glen Biglaiser, Quan Li, Edmund Malesky, Pablo Pinto, Santiago Pinto, and Joseph Staats. (2012) Politics and Foreign Direct Investment. Ann Arbor: University of Michigan Press.
Kaldor, Mary. (1999) New Wars and Old Wars: Organized Violence in a Global Era. Stanford: Stanford University Press.

Karatnycky, Adrian. (2005) Ukraine's Orange Revolution. Foreign Affairs 84 (2): 35-52.

Kurzman, Charles. (1996) Structural Opportunity and Perceived Opportunity in Social-Movement Theory: the Iranian Revolution of 1979. American Sociological Review 61 (1): 153-170.

Lake, David A. AND Donald S. Rothchild. (1998) The International Spread of Ethnic Conflict: Fear, Diffusion, and Escalation. Princeton: Princeton University Press.

LI, Quan. (2006) Political Violence and Foreign Direct Investment. In Research in Global Strategic Management, Volume 12, Regional Economic Integration, edited by Michele Fratianni and Alan M. Rugman. Amsterdam: Elsevier Ltd.

LI, Quan. (2009) Democracy, Autocracy, and Expropriation of Foreign Direct Investment. Comparative Political Studies 42 (8): 1098-1127.

Li, Quan And Adam Resnick. (2003) Reversal of Fortunes: Democratic Institutions and Foreign Direct Investment Inflows to Developing Countries. International Organization 57 (01): 175-211.

Markusen, James R. (2001) Contracts, Intellectual Property Rights, and Multinational Investment in Developing Countries. Journal of International Economics 53 (1): 189-204.

McAdam, Doug, John D. McCarthy And Mayer N. Zald, Eds (1996) Comparative Perspectives on Social Movements: Political Opportunities, Mobilizing Structures, and Cultural Framings. New York: Cambridge Univ Press.

Montiel, Cristina and Victoria M. Chiongbian. (1991) Political Psychology in the Pjhilippines. Political Psychology 12 (4): 759-777.

Murdoch, James C. ANd Todd SAndler. (2004) Civil Wars and Economic Growth: Spatial Dispersion. American Journal of Political Science 48 (1): 138-151.

Olson, Mancur. (1993) Dictatorship, Democracy, and Development. American Political Science Review 87 (3): 567-576.

OneAl, John R. (1994) The Affinity of Foreign Investors for Authoritarian Regimes. Political Research Quarterly 47 (3): 565-588.

Sachs, Jefrrey. (2006) The End of Poverty: Economic Possibilities for Our Time. New York: Penguin.

Schneider, Friederich AND Bruno S. Frey. (1985) Economic and Political Determinants of Foreign Direct Investment. World development 13 (2): 161-175.

Svensson, Јаков. (1998) Investment, Property Rights and Political Instability: Theory and Evidence. European Economic Review 42 (7): 1317-1341.

Weinstein, Jeremy M. (2007) Inside Rebellion: The Politics of Insurgent Violence. New York: Cambridge University Press. 